\title{
Language Style Operated by Indonesian Minister of Education to Urge Indonesians to Learn from Covid-19 Pandemic as Character Leadership Value
}

\author{
Chalimah, Ainiyah Mahmudah
}

STKIP PGRI Jombang

chalimahstkipjb@gmail.com

\section{Article History}

received $1 / 9 / 2021$

\begin{abstract}
Language style is operated to convey ideas and thoughts as well as to express intentions and to show who the speakers themselves. In the era of glory for You-tube, this research focuses on categorizing the language style used by the Indonesian Minister of Education in Najwa program uploaded in Najwa You-tube channel. The researcher used qualitative research to analyze and describe language style used in the transcript of video interview and document analysis. The data of this research is in the form of utterances. The data analysis technique was obtained through qualitative analysis by doing three steps; organizing and familiarizing, coding and reducing, and interpreting and representing. Researchers only found 3 styles, namely: casual style, intimate style and consultative. This research gives contribution in learning the character leadership shown by the Indonesian Minister of Education.
\end{abstract}

Keywords: language style, character leadership value, learn from Covid-19 pandemic

\section{Abstrak}

Gaya bahasa digunakan untuk menyampaikan ide, pemikiran, maksud dan menunjukkan siapa penutur. Di era jayanya You-tube, penelitian ini fokus untuk mengkategorikan gaya bahasa yang digunakan oleh Menteri Pendidikan di program Najwa yang diunggah dalam Najwa Youtube channel. Peneliti menggunakan penelitian kualitatif untuk menganalisa dan mendeskripsikan gaya bahasa dalam bentuk script video iwawancara dan dokumen analisis. Data penelitian adalah dalam bentuk ujaran. Teknik analisis data didapatkan melalui analisis kualitas dengan tiga langkah: pengelompokan dan pengenalan, pengkodean dan reduksi data, interpretasi dan representasi. Peneliti hanya menemukan 3 gaya yaitu gaya santai, gaya akrab dan gaya konsultatif. Penelitian ini memberikan kontribusi dalam pembelajaran tentang karakter pemimpin yang ditunjukkan oleh Menteri Pendidikan Indonesia.

Kata kunci: gaya bahasa, nilai karakter pemimpin, belajar dari pandemi Covid-19

Social, Humanities, and Education Studies (SHEs): Conference Series https://jurnal.uns.ac.id/shes

p-ISSN 2620-9284

e-ISSN 2620-9292 


\section{INTRODUCTION}

The language has an essential role to show the cultural characteristics and the social level which is owned by people. The people need to use language style to influence people to trust and follow their instruction. The more complex language style used shows the social level and the high culture (Wildan, 2014). The objective of this research is to explore how the language style or the speech style used by a leader in government, especially for the Indonesian minister of education. This research fills the gap of the previous researches that explores the language style from the leader in government in social media through You-tube in Covid-19 Pandemic era seen from the previous studies in Sakti \& Weda (2020) that investigated the speech style of movie, Putra \& Rosa (2019) that investigated the speech style in Ellen Degeneres talk show, Astika (2018) that investigated the speech style in Kick Andy talk show, Amirudin \& Matlub (2013) that investigated the speech style in Novel.

This research contributes to show the language style as well as the character value of leader. There are two significances of the research, namely: giving the theoretical contribution to support Joos' theory (in Sakti \& Weda, 2017) used in valuing utterances by determining the utterances categorized in intimate style, casual style, consultative style, formal style and frozen style. This research practically gives contribution to show how the public figure in academic field shows his character value through his utterances.

\section{METHOD}

Language style is a part of sociolinguistics which learns about the ability of the speaker to speak and the ability of hearer understands the speaker (Akmajian, et.al., 2010). The speakers need pay attention to factors considered in their speaking, such as: (1) setting and scene, the speakers know the right time and place to speak and consider the abstract physical condition so that the speakers decide to be serious or unserious, (2) participants, the people know the position as speaker or listener so that they get different role in conversation, (3) ends, the speakers have their personal or social purpose, goal, and outcome to speak, (4) act sequence, it refers to what they say in some events, such as in lecture, in casual conversation, and in party, (5) key, the speakers use tone and manner to show particular message in mocking, sarcasm, seriousness, and many others, (6) instrumentalities, they refer to the register and dialect chosen to make them more closed, (7) norms of interaction, they refer to the norms in speaking, namely: loudness, silence, and gaze return, (8) genre, the speakers understand their types of utterances to achieve their speaking goal (Nisa, 2019).

The language can be various with same information delivered by considering who uses the language, where and to whom the language is used (Holmes, 2013). The speech style or language style are divided into several types stated in Sakti \& Weda (2017), namely: (1) formal style, it is used in formal situation by considering good grammar and good vocabulary. (2) casual style, it is used in informal situation by having conversation with friends and family (3) intimate style, it is used when the speaker only discusses about what another speaker talks about and avoids talking about another topic which is discussed, (4) consultative style, it is used when the speakers are in semi formal situation for instance in discussion between teacher and student, doctor and patient, (5) frozen style, it is used in respectful events for instance in anthems, marriage, laws.

The researcher used a qualitative research method by analyzing and describing the transcripts video interview as a part of human problem to be described (Creswell, 2014). In this case, the researchers used the document analysis to find out the specified characters in the interview done in You-tube (Ary, et.al., 2010). The research focuses on analyzing and interpreting transcript of video interview conducted by Najwa Shihab to Nadiem Makarim as Indonesian Minister of Education and Culture taken from 
You-tube with the title 'Belajar dari Pandemi: Normal Baru dan Teori Konspirasi'. The duration of the video is 30.10 minutes. The key instrument is nonparticipant observation by watching and recording the situation under study without any involvements with the participants or current setting. This technique was chosen by the researcher to analyze the utterance so that the researcher would absolutely become an observer. The researcher observed the form of utterance in the interview that had been uploaded in Najwa. The observation focuses on the type of language style.

The interview was conducted for 30.10 minutes and researchers used only half of the sample. Researchers collected in the form of document (transcripts) that are used as research evidence with the following collection techniques. The first, the researcher watched the video from Najwa Shihab channel with the title 'Belajar dari Pandemi: Normal Baru dan Teori Konspirasi'. The second, researchers collected the document form the transcripts interview. Data collection was taken by the researcher typing the utterance contained in the interview. Thirdly, the researcher found the utterances in language style. Fourthly, researchers examined all of the data to know if it is appropriated with the theory that the researcher has read. After collecting the data, the next step is analyzing the data. The data analysis technique in this study was obtained through qualitative analysis (Gay, Mills \& Airasian, 2000). In organizing and familiarizing step, the researchers organize the data in the form utterance used by the speaker. In coding, the researchers make coding to show the type of language style in speech that contains language style. In interpreting and representing, the researchers interpret and represent the data related to the type of language style.

\section{FINDINGS AND DISCUSSION}

In this study, the researchers only find consultative style, casual style and intimate style. Here is the description of language style which is found in this research.

\section{Consultative Style}

"Terutama adalah selalu menggunakan akal sehat dalam memfilter informasi, sehingga kita bisa juga mengontrol reaksi emosional kita terhadap semua informasi tersebut, karena bawaannya mau panik bawaannya kan ketakutan". (CTS)

The purpose of utterance is to provide answers or information about how to fight a pandemic which is like a world war. Guest said that common sense is needed to filter information that can come from anywhere. If you can filter this, people can control their emotions more about various information. If we can't control it, it will unconsciously create panic and fear. The utterance included in to consultative style kind of language style. This style shows our norm with strangers but whose personal stock of information may be different. In the utterance, the speaker uses a fairly formal language, but it is lower than the formal style. From these characteristics, it indicates that the language style used is a consultative type.

"Dua sektor yang terpenting menurut saya akan berubah adalah pendidikan dan kesehatan" (CTS)

Based on the data above, the speaker said that this pandemic has changed many things, especially in the education and health sectors. The utterance included in to consultative style kind of language style. The situation used in the utterance is a semi-formal situation. The speaker gave an answer about the host's question that changes that occurred during the pandemic.

\section{Casual Style}

"Udah dirumah enam minggu ini." (CS)

The speaker said that due to the pandemic and the implementation of the lockdown, all activities were carried out at home and had been running for six weeks. The utterance included into casual style kind of language style. The situation that 
occurred at that time was in a relaxed situation. The guest's response used colloquial such as 'udah (sudah).

"Tapi ya secara psychologis pasti ada dampaknya lah, e...ee...dampak negatifnya gitu kan" (CS).

The speaker uses everyday language to respond to the other person. The utterance included in to casual style kind of language style. The casual style is usually applied for friend and family. The speaker uses an additional morpheme that is commonly used in everyday such as "lah, kan". The word "lah" in the utterance is used as an affirmation or reassurance that the pandemic must have an impact. In addition, the "kan" in the utterance is used to confirm the meaning of the question. This sentence indicated inaccurate sentence viewed from grammatical rules. The guest also used colloquial such as "gitu (begitu)".

"Jadinya ini defining moment buat banyak sekali pemimpin-pemimpin politik, pemimpinpemimpin bisnis, pemimpin masyarakat kita memilih jalur yang mana?” (CS)

The data is the defining moment for leaders which path should leaders take. The utterance included in to casual style kind of language style. He uses more relaxed communication and the situation seemed less formal. The speaker uses a combination of Indonesian and English in their utterances. The guest's response used colloquial such as 'jadinya (jadi)'.

"Karena bawaannya mau panik bawaannya kan ketakutan". (CS)

The data explains that the biggest challenge people face is controlling emotional reactions. The utterance included in to casual style kind of language style. The language used by the guest is the language used in everyday life. The situation when the conversation occurs is a relaxed situation. The guest's used colloquial such as 'bawaannya (membuat)'. The word "bawaannya" is usually found in everyday language. Then, the word "kan" in this utterance is used to emphasize if we cannot control our emotion, we will feel scared.

"Tapi ironisnya, kalau semua orang hanya memikirkan dirinya sendiri semuanya gagal ya kan?" (CS)

The data says if everyone only thinks about themselves then this pandemic will not end. However, if everyone works together, the pandemic will be easier to overcome. The utterance included in to casual style kind of language style. The situation is normal and relax. The speaker uses the words "ya, kan" for emphasis.

"Bayangkan kalau semua negara melakukan efektif pengcontaingent Covid tapi ada satu negara yang tidak melakukan, lalu semuanya sudah kelar Covid di negara lain, ini nanti akan menyebar lagi”. (CS)

The speaker said that if there were a country that did not participate in the contingent to solve COVID, the pandemic would not end. In his speech, the speaker uses everyday language to convey his opinion. The utterance included in to casual style kind of language style.

"Mungkin kita.....kita udah biasa menyebut itu tapi belum pernah merasa seperti itu ya seberapa pentingnya udah berapa kali Mbak Nana menghubungi keluarga di masa Covid ini" (CS)

The speaker tells the changes that occur when facing the new normal. He said that one of the changes was that he cared more about his family. The utterance included in to casual style kind of language style. In addition, there is repetition of words and also the guest uses some words that are not needed so that the sentence is not efficient.

"Yang ketiga menurut saya yang akan menjadi normal baru adalah seberapa pentingnya kesehatan ya kan? Kesehatan itu selalu kita taruh di background, apalagi buat anak-anak muda". (CS) 
The utterance argues that most young people are not very aware of health. The sentence is also influenced by the situation and condition of the participant, where the condition of the participant is in a relaxed and informal situation.

"Teknologi yang selama ini dianggap ya bisa untuk melakukan itu tapi this is totally the next level ya ada betul-betul hampir semuanya bisa kita lakukan lewat teknologi". (CS)

Speaker says that today's technology has become an important element for people. The utterance included in to casual style kind of language style. The words used in the utterance are familiar words such as "really". The utterance used colloquial such as really (true), but. In addition, the speaker added some unnecessary words, thus making the sentence less effective.

\section{Intimate Style}

"Apa kabar Mbak Nana?" (IS)

The utterance included in to intimate style kind of language style. When the speaker greets by using a closed call as 'mas, mbak'. This term is usually used completely private language used by some people who are familiar.

"Itu adalah cara berpikir malas, sedangkan kalau kita percaya kepada scientist-scientist ini sudah diprediksi bertahun-tahun Mbak Nana ya kan?" (IS)

The speaker answers the question about the existence of conspiracy theories and blaming each other on several parties. In the utterance above the guest uses a familiar greeting. The utterance included in to intimate style kind of language style. One of the characteristics of intimate style is using a nickname to communicate with the other person. The guest uses the call "mbak" at the end of the sentence. From the findings that the minister tends to use casual type more than intimate style and consultative style shows that the leader shows the humble and kind character by getting closer to people whom he talks with as friend or as family. The way to communicate well with others can happen when the people whom we talk with feels comfortable (Sakti \& Weda, 2017) and know the appropriate way to interact (Akmajian, et.al., 2010). The language really pictures the speaker who uses it because the language can be delivered in some different ways with the same information and describes who uses the language style, where and to whom the language is used (Holmes, 2013).

\section{CONCLUSION AND SUGGESTION}

The good leader tends to use the casual type more than intimate style to be closer to people whom they talk with but still see the limits to be appreciated. The consultative style is used by the leader to urge the people to think and answer the questions themselves to decide to accept or refuse negative thought by using a leading question.

This research has still a lack that it has not investigated deeply in stylistic matter and the implicit meaning in pragmatic field to be continued in the next research.

\section{REFERENCE}

Akmajian, A., Demers, R.A., Farmer, A.K., and Harnish, R.M. 2010. Linguistics: An Introduction to Language and Communication. The MIT Press: England.

Amirudin, M. and Matlub. 2013. "An Analysis of English Speech Style as Reflected by the Main Character of a Tale of Two Cities." Jurnal Kependidikan Interaksi Vol. 8, No. 2, pp. 76-83.

Ary, D., Jacobs, L.C., and Sorensec, C. 2010. Introduction to Research in Education. Wadsworth Cengage Learning: Canada.

Astika, S. 2018. "The Analysis of Speech Style Used in Kick Andy Talkshow.", Research in English and Education. Vol. 3, No. 2, pp. 154-162. 
Creswell, J.W. 2014. Research Design: Qualitative, Quantitative, and Mixed Method Approaches. SAGE: United States of America.

Gay, L.R., Mills, G.E., and Airasian, P. 2020. Educational Research. Pearson: United States of America.

Holmes, J. 2013. An Introduction to Sociolinguistics. Routledge Taylor and Francis Group: London and New York.

Nisa, S.U. 2019. Sociolinguistics. Retrieved from Research Gate. Diakses pada https://www.researchgate.net/publication/331285240_Sociolinguistics/link/5c7d5 e57299bf1268d3905f5/download

Putra, E.T. and Rosa, R.N. 2019. "The Analysis of Speech Style Used by Ellen Degeneres in Ellen Talk Show." E- Journal of English Language and Literature. Vol. 8, No. 3, pp. 317-328.

Sakti, A.E.F and Weda, S. 2020. "The Kind of Speech Styles in Allan Plenderleitth's The Bunker Movie." ELS-Journal on Interdisciplinary Studies on Humanities, Vol. 3, No. 3, pp. 376-392.

Wildan. 2014. "Fungsi Kemasyarakatan Bahasa dalam Perspektif Kajian Sosiologi Linguistik."Kariman, Vol. 2, No. 2, pp. 85-96. 